University of Texas Rio Grande Valley

ScholarWorks @ UTRGV

Political Science Faculty Publications and

Presentations

College of Liberal Arts

$9-3-2021$

\title{
Lone Star Wars: LNGs, Communities, and Globalization versus Local Resistance in the Laguna Madre Region of Coastal South Texas
}

Terence Garrett

The University of Texas Rio Grande Valley, terence.garrett@utrgv.edu

Arthur Sementelli

Florida Atlantic University, sementel@fau.edu

Follow this and additional works at: https://scholarworks.utrgv.edu/pol_fac

Part of the Political Science Commons

\section{Recommended Citation}

Garrett, T. and Sementelli, A. (2021), "Lone Star Wars: LNGs, communities and globalization versus local resistance in the Laguna Madre region of coastal South Texas", Journal of Global Responsibility, Vol. 12 No. 4, pp. 452-468. https://doi.org/10.1108/JGR-03-2021-0035

This Article is brought to you for free and open access by the College of Liberal Arts at ScholarWorks @ UTRGV. It has been accepted for inclusion in Political Science Faculty Publications and Presentations by an authorized administrator of ScholarWorks @ UTRGV. For more information, please contact justin.white@utrgv.edu, william.flores01@utrgv.edu. 


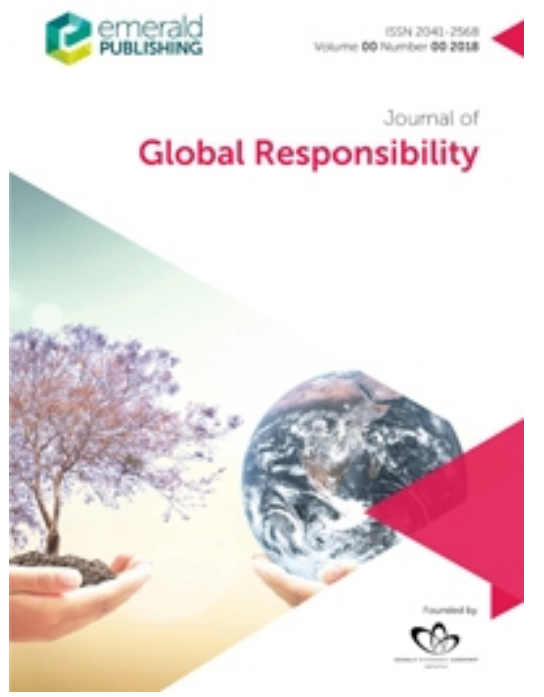

\section{Lone Star Wars: LNGs versus Communities, Corporate Globalization versus Local Resistance in the Laguna Madre Region of Coastal South Texas}

\begin{tabular}{|r|l|}
\hline Journal: & Journal of Global Responsibility \\
\hline Manuscript ID & JGR-03-2021-0035.R2 \\
\hline Manuscript Type: & Research Paper \\
\hline Keywords: & $\begin{array}{l}\text { Corporate responsibility, Environmental impact, LNG, Spectacle, } \\
\text { Collateral damage, NIMBY }\end{array}$ \\
\hline
\end{tabular}

\section{SCHOLARONE ${ }^{m}$ Manuscripts}


Lone Star Wars: LNGs, Communities, and Globalization versus Local Resistance in the Laguna Madre Region of Coastal South Texas

Purpose: to theoretically contextualize the Liquefied Natural Gas (LNG) issue using Bauman and Debord. More generally, this research provides a theoretical and qualitative context to understand the LNG issue in discussions of environmental management, globalization, and local government.

Design/methodology/approach: this article uses Boje's narrative case study approach to analyze the politics around localized resistance movements to LNG production in the Rio Grande Valley. Specifically, the study examines data collected from the Federal Energy Regulatory Commission (FERC), personal interviews, and public declarations (newspapers, blogs, social media) to create an historiographical account of LNGs in the RGV to analyze the Laguna Madre resistance case regarding three LNG companies.

Findings: the development of LNG in Laguna Madre has been at least temporarily halted. This is considered partially due to the pandemic, reduced demand, and local resistance. In the Laguna Madre case, controlling narratives by the LNG resistance appeared to be an essential component of their overall strategy.

Originality/value: understanding the impact of energy development locally and globally becomes increasingly important as access to fossil fuels become more limited. This case helps understand the overall adverse actions taken by LNGs to exploit communities, individuals, and the environment while illustrating practical tools being employed to resist the less desirable elements of energy development.

Keywords: LNG, spectacle, collateral damage, NIMBY, corporate responsibility, environment

\section{Introduction}

The fossil fuel export industry in general, specifically liquefied natural gas (LNG), evokes public criticism in both the social and political dimensions. More specifically, there is an observed tendency to resist hegemonic behavior surrounding location decisions for LNG terminals in the United States. These location decisions are often seen as antithetical to the interests of property owners and people more generally in the region of Laguna Madre, located in South Texas along the border with Mexico. One of the first reactions includes employing specific narratives to invoke legal reactions to hegemonic decisions. In general, locating LNG 
facilities is problematic given the existing risks for contamination of properties, the associated plume of impact, and of course, the risk of catastrophic explosion.

Despite these risks and resistance, the process of locating to the Port of Brownsville is well underway. It remains unclear if fossil fuel industries will continue to pursue locations in the region. Global market conditions continue to shift impacting whether or not LNG terminals will locate near the port of Brownsville. Underlying these decisions, however, are consistent examples of hegemonic behavior and its associated narratives (Garrett 2018). The narrative case study employed in this article illustrates the theoretical impact of Bauman and Debord using the approach created by Boje to uncover how property owners, environmental groups, indigenous people, and small businesses have created narrative responses to the hegemonic decision-making practices being employed for location decisions in the Laguna Madre region.

\section{Conceptual background}

Any discussion of hegemonic decision-making needs to be framed within a theoretical context. Specifically, we rely upon French situationist - Debord (2006) combined with Bauman's (2011) postmodern approach [1] to the concept of collateral damage. Debord (2006) contributes through his discussion of commodifiable fragments, the reign of the market economy, and the notion of front facing appearances. Bauman's (2011) application of collateral damage highlights the unintended, unanticipated, and otherwise unplanned effects of market driven decisions. Briefly, the combination of these two conceptual elements elegantly captures the context of the LNG issues being explored in this article. This, in turn, extends, earlier narrative examinations of this issue (Garrett 2018). Additionally, this fusion of two concepts situates itself within the work of Van de Graaf and Sovacool (2020) on "contested frames" whereby their...

...analytical framework is essentially constructivist and serves to capture the complexity and diversity of individual views on global energy issues. Each frame has a different take on what is happening, what is causing it, and what can be done in the world of energy. They incorporate foundational assumptions about how the world of energy works (16). In the context of the Laguna Madre, the philosophical position of Van de Graaf and Sovacool $(2020,17)$ corresponds with the "radical humanist" theoretical framework (Ardalan 2016) being 
developed, as the economically and politically more powerful and dominant pro LNG actors employ a worldview that is neo-mercantilist and adhere to the principles of market liberalism. Conversely, the environmental and community resistance groups in the lower Laguna Madre are advocates of property ownership, environmentalism, and egalitarianism, meeting the criteria for a contested frame.

Within this contested frame, it becomes important to understand the sort of environmental, property driven, and community driven narratives commonly employed. Consequently, it is important to include a discussion of NIMBY, property contamination, and plume of impact research. These existing scientific and legal narratives serve as evidence to support Debord (2006) and Bauman's (2011) research on spectacles and collateral damage, respectively informing a more mainstream argument focusing on related concepts drawn from the environmental justice and disparate impact literature from urban and regional planning. This body of literature includes concepts that are ready-made narratives challenging hegemonic efforts. Subsequently, these narratives allow resistance groups to employ economic logic, while allowing us as researchers to consider the impact of LNGs on local governments, on citizens, and the environment more generally. The context becomes particularly interesting when one considers that the Rio Grande Valley communities of South Padre Island, Port Isabel, Laguna Vista, and Laguna Heights, Texas are among the poorest metropolitan planning organization areas of the United States, highlighting environmental justice concerns.

\section{Revisiting risk and uncertainty}

Continuing the examination of Bauman's (2011) collateral damage combined with Debord's (2006) understanding of spectacle, we must next reconsider risk and uncertainty. LNG facilities, transportation, and other distribution elements carry associated risks alongside uncertainty about safety, profits, and other factors. As such, there is an associated set of stigmas tied to the LNG industry. When we think of stigma in the context of environmental justice, we are really looking at notions of stigma and value for physical property (Mundy 1992; Sementelli \& Simons 1997; Simons \& Sementelli 1997). Previous research has examined impacts of underground storage tanks (Sementelli \& Simons 1997; Simons \& Sementelli 1997) and fuel oil contamination (Closser, 2001). More recent research has extended this notion of stigma to include abstract concepts more like government itself (Moura \& Miller 2019). Interestingly, the 
LNG industry with its market spectacle and questions of collateral damage continues to capture both conceptions. Subsequently, media outlets have begun to bring discussions of health risks to the forefront (Hopper 2021). As people become cognizant of risk, it then becomes necessary to consider LNG as a NIMBY issue.

\section{NIMBY: Not in my backyard}

When experiencing collateral damage (Bauman, 2011) in the context of a market spectacle (Debord 2006) people in general, and property owners in particular tend to try and protect their valuable items including land. The NIMBY problem refers to situations where people object to locating specific projects that are understood to be detrimental, undesirable, unpleasant, or even hazardous. Decision makers, citizens, and other impacted individuals often are not conceptually opposed to the project as long as it is not near them giving rise to the acronym NIMBY or not in my back yard. One of the key elements of the NIMBY argument involves the uneven distribution of risk, meaning that less wealthy, nonwhite, less advantaged people are often those who assume the most risk.

Urban planners typically focus on methods to overcome NIMBY (Dear, 1992) based on arguments for the merits of some project. This is especially true in the energy sectors (DevineWright, 2014). Property owners tend to be a risk averse when it comes to decisions that compromise the value of their land. Though a project might have economic merit, the environmental impacts tend to skew risk away from the wealthy, hegemons, and politically powerful towards the disadvantaged consistent with work in critical sociology (Gibson 2005) which in turn sets up collateral damage theory.

\section{Collateral damage theory}

Bauman's (2011) application of collateral damage borrows judiciously from a variety of literature streams including environmental justice, and critical theory more generally to articulate a great asymmetry between haves and have nots. Though this is hardly a novel concept, it is a useful interpretation of the more mainstream environmental justice literature which focuses on the struggle for safe and healthy environment by linking it explicitly with Marxist theories. Specifically, there is an interesting undertone to environmental justice theory that often emphasizes concepts like participation, function, and flourishing (Schlosberg 2009) that typically reflect more widely held professional beliefs in urban planning. However, something idealized is 
not always achievable (Heilman \& Sementelli 2020). In practical terms, hegemonic actors often work against the 'collective good' idealized by urban planners allowing us to reconsider LNG placement in the lower Rio Grande Valley/Laguna Madre region and how it works against environmental justice.

Bauman (2011) focuses on what critical theorists might call a neo-liberal approach to power and politics around the assumption of risk. Hegemonic oppression in this case is manifested through economic decision-making rather than something that is wholly political. A consequence of this manifestation includes the possibility of "power without politics and politics without power" (p. 23) illustrating another example of the hollow state (Milward \& Provan 2000) in administrative thought. In the case of LNG terminals, Bauman's (2011) application of collateral damage is an economic concept, representing a classic argument for shifting negative externalities to local political units, citizens, and the disadvantaged thereby supporting both globalization and neoliberal economic thought to the detriment of public environmental justice concerns.

Theoretically, this assertion by Bauman (2011) is supported by Agamben $(1993,79)$ who notes "When the real world is transformed into an image and images become real, the practical power of humans is separated from itself and presented as a world unto itself. In the figure of this world separated and organized by the media in which the forms of the State and the economy are interwoven, the mercantile economy attains the status of absolute and irresponsible sovereignty over all social life.” Bauman (2011, 23; in Garrett 2018,59) states that there is now a "power free from politics, and politics devoid of power" - power that is globalized while “politics stay pitifully local. Territorial nation-states are 'local law and order' police precincts, as well as local dustbins and garbage removal and recycling plants for the globally produced risks and problems." This in turn, allows us to employ the "collateral damage' argument (Bauman 2011) alongside Debord (2006/1967) to enrich our narrative analysis of the Laguna Madre case. 


\section{The Spectacle}

If we unpack the LNG arguments further, we identify links to Debord (2006/1967) as the narratives are economic in nature, and antidemocratic especially when considering differential impacts of the risk involved and are conveyed by mass media. Specifically, we uncover the prioritization and fetishization of capital production over the lives of the affected masses. In this case hegemonic decision-making narratives are presented as something desirable, allowing them to be a part of a broader NIMBY argument although without the equality taken as an a priori assumption in urban planning. The particular kind of hegemony in this case can be understood as opportunistic hegemony (Yarbrough \& Yarbrough 1987; 1987b; Ogbor 2001), which is closest conceptually even though it is most often applied in the context of corporate culture. Despite the differing context, opportunistic hegemony remains conceptually close to being an ideal representation (Ives 2004) particularly when we talk about narratives and language.

\section{Methodology}

This research uses the narrative case study approach developed by Boje (1995, 2001, 2008). Boje's approach is ideal since it captures the fragmented, collective, underdeveloped, and otherwise messy elements of storytelling and narratives. The data was collected from multiple fragmented sources including the Federal Energy Regulatory Commission (FERC), personal interviews, and public declarations (newspapers, blogs, social media) to provide an accurate, but likely incomplete picture of the actions undertaken by multiple actors in regarding the LNG production in the Rio Grande valley. This qualitative approach is superior since it limits the possibility of 'counterfeit coherence,' which is often a problem in other narrative approaches.

We were also able to incorporate narrative fragments from US Fish and Wildlife, SpaceX Corporation, the Port of Brownsville, along with internet and social media narratives from LNG LLCs. These fragment composite narratives illustrate stories of economic prosperity, environmental hardship, job creation, and risk - all forming a mosaic that makes up the story of the Laguna Madre. Moreover, the narratives demonstrate how questions of collateral damage, antidemocratic practices, and neoliberal economic policies move in and out of the public eye as part of a greater spectacle. 
Debord (2006/1967) in particular, highlights the issues of opportunistic hegemony (Yarbrough \& Yarbrough 1987;1987b; Ogbor 2001) by the LNG refinery corporations as well as the collective resistance to their efforts. Debord (2006/1967) enriches this discussion of hegemony by highlighting the "sham struggles of rival forms of separate power" (p. 56) that are "defined by specific peculiarities in the varieties of production and power" (ibid) and passed off within the spectacle as a distinct form. This 'distinct form' is ultimately just a small facet of the neoliberal economic system of capitalism making the narratives of debate and dialogue ultimately elements of spectacle (Debord 2006/1967).

\section{Study Area}

The Laguna Madre study area is a region in South Texas where the Rio Grande flows into the Gulf of Mexico (Garrett 2018). The area is a study of contrasts. It is poor, industrialized, part of the commercial space aviation industry, as well as a tourist destination, commercial transit hub, and part of the energy sector. Given this context, residents of communities in the region are seen as being nearly powerless to challenge the global fossil fuels industry. Laguna Madre communities have little influence in Washington, D.C., while the area simultaneously exhibits signs of industry capture (Rubinstein Reiss, 2012). This allows for prevailing narratives that focus on economic development over the local environment to flourish. It becomes clear that it was necessary to use Boje's narrative approach applied to the theoretical frame that combines Debord (2006/1967) with Bauman (2011).

The following sections analyze narratives regarding the potential construction of natural gas pipelines approved by the Federal Energy Regulatory Commission (FERC) as the former Valley Crossing Pipeline LLC, purchased by Enbridge 2019, was built originally in 2018. In addition to Valley Crossing Pipeline, Enbridge bought Rio Bravo Pipeline LLC from NextDecade's Rio Grande LNG in 2020 as we will see below. FERC approved all three LNG LLC terminals in November 2019 to be constructed. We begin the narrative analysis examining the initial siting of LNGs in the area, possible effects on the environment, existential threats involving the volatility of LNG processing and proximity to SpaceX rocket launches, and local resistance to the establishment of LNGs. 


\section{From hydraulic fracturing to LNG refineries}

As laid out in Garrett $(2018,59)$ "liquefied natural gas (LNG) is presented as a clean energy alternative by oil and gas corporations to replace the more toxic and pollutant coal." The Center for Liquefied Natural Gas (n.d. para.1-2) under its web site heading titled "LNG and the Environment" illustrates this as "Natural gas, like other energy sources, has an impact on the environment. That impact has been largely positive over the last two decades, as greater use of natural gas and LNG have contributed to reduced carbon emissions and provided reliable support and back-up for renewable energy." This assessment does not hold up. Methane gas, like any other hydrocarbon produces significant amounts of carbon dioxide during combustion. Hydraulic fracturing (fracking) extracts oil and gas from shale formations by using high water pressure (U.S. Geological Survey n.d. para. 1). Extracting these fossil fuels from shale is not ideal since it releases more contaminants than other extraction methods in other areas. Known side effects according to the USGS include both earthquakes and degradation of groundwater quality. LNG, of course, can be extracted through fracking.

Other environmental risks emerge once natural gas is captured. Transportation of LNG products during various stages of refinement have accompanying risks (The Union of Concerned Scientists February 3, 2014, 5; Garrett 2018, 61). As an example, methane is 34 times more potent than carbon dioxide at trapping heat (ibid) making it a climate change concern though it is less often considered. Rather, advocates typically present evidence that LNG is cleaner than coal, which is more of a condemnation of the coal extraction process (especially strip mining, which leaves far more visible damage) than it is an affirmation of how clean LNG is. In contrast, methane is far less visible as a pollutant making their narrative pitch for a 'clean sufficiently safe fuel' reasonable particularly in the context of being a transitory fuel.

\section{Coming to a beach near South Padre Island: LNG refinery sites and tankers at the Port of Brownsville and deepening the Brownsville shipping channel}

We could be the largest center for $L N G$ exports in the Western Hemisphere. - Port Director and CEO Eduardo Campirano, Port of Brownsville (Chapa April 24, 2015).

LNG came to us. We didn't go to LNG. - Eduardo Campirano, CEO of the Port of Brownsville (Corso August 8, 2019).

Buried in a Brownsville Herald newspaper article (Clark April 25, 2012) titled "Cargo up 16 percent over 2010 at Port of Brownsville," was a paragraph that indicated five LNG limited 
liability companies (LLCs) were leasing land along the Brownsville shipping channel. The five companies cited were Rio Grande Liquefied Natural Gas (RGLNG), Annova LNG, Texas LNG, Sideco LNG and Gulf Coast LNG. The latter two LLCs did not pursue their respective projects but Rio Grande LNG (NextDecade Corporation) which also had the Rio Bravo Pipeline LLC was sold to Enbridge February 23, 2020. That pipeline is not yet completed. As of March 22, 2021, Annova LNG (Exelon Corporation) has decided not to move forward with the construction of its terminals and at least publicly is halting its operations, making a claim that it was due to the global natural gas market (Hydrocarbons-Technology.com March 23, 2021). RioGrande LNG and Texas LNG (Glenfarne Group and Samsung Corporation) are presently attempting to begin operations in the future. Construction timelines for natural gas pipelines and refineries have been slowed by global market forces and local resistance in the Laguna Madre community (more below). Since the Brownsville Herald story broke, the only aspect of the project completed thus far is the Valley Crossing Pipeline that extends from the Agua Dulce region near Kingsville, Texas that was sold to Enbridge. There are obstacles for getting Federal Energy Regulatory Commission (FERC) approval, but this is the current status for LNG terminals as reported by the LLCs below:

\section{Rio Grande LNG}

Project facts: 984-acre site optimally located in the Port of Brownsville, Texas...Total capacity of 27 million metric tonnes per annum (mtpa)...4 x 180,000 m3 full-containment LNG storage tanks...Deepwater port access with supporting marine infrastructure...Two marine jetties, berth pocket, turning basin...Abundant gas supply from the Permian Basin and Eagle Ford Shale (Source: RGLNG n.d.)

\section{Annova LNG}

Annova LNG is a 6.5 MTPA liquified natural gas (LNG) export facility on the Port of Brownsville, Texas deep water channel. With an experienced leadership team and investment-grade equity owners, including Exelon Corporation, Black \& Veatch Corporation and Kiewit Corporation, Annova LNG is a leader among second-wave U.S. LNG facilities... Located on 731 acres along the south side of the Brownsville Ship Channel, the purpose of the Annova LNG facility is to receive natural gas from the Agua Dulce, Texas region, provide any treatment necessary before, chill the natural gas until it condenses into LNG, store such LNG pending loading for tanker transport, and load the LNG onto LNG tankers for export to other countries...(Annova LNG n.d., para. 1). 


\section{Texas LNG}

Texas LNG's 625+ acre site is strategically located on the Port of Brownsville's deepwater ship channel. Texas LNG will have a permitted capacity to produce 4 MTA (million tonnes per annum) Liquefied Natural Gas (LNG). The project will have two trains using the standard Air Products liquefaction technology producing 2 MTA each...Texas LNG will export LNG to global LNG markets. Texas LNG has received its Department of Energy authorization to export to both FTA and non-FTA markets... The Final Environmental Impact Statement was issued in March 2019. Texas LNG received its FERC authorization in November 2019...Texas LNG plans to reach Final Investment Decision (FID) in late 2021, contingent on many factors such as completing the required commercial agreements, securing all necessary permits and approvals, obtaining financing and incentives, and other factors associated with commercial viability of the investment. Construction will begin after FID and first LNG exports commencing in 2025 (Phase 1). Phase 2 exports expected to commence soon thereafter. (Source: Texas LNG "Texas LNG summary" [n.d.], para. 2-6, italics added for emphasis).

The three LNG LLCs - Annova LNG (169 FERC \ 61,132), Texas LNG (169 FERC ๆ 61,130), and Rio Grande LNG / Rio Bravo Pipeline (169 FERC \ 61,131)-received authorization orders to begin their respective projects effective November 22, 2019, pending final approvals from the Army Corps of Engineers and other state and federal agencies. FERC Commissioner Glick dissented with Commissioner Chatterjee (chair) and Commissioner McNamee approved in all three cases. What is not shown on the LNG websites is that the proposed LNG terminals are close and, in some cases, are within two to three miles of population centers potentially stigmatizing them and raising NIMBY concerns. The prevailing narrative from the Texas LNG, Rio Grande LNG, and Annova LNG websites is that there is positive economic development with little to no environmental degradation in the affected areas.

There is a secondary problem for the LNG sites. The Brownsville shipping channel is only 42 feet deep and it has to be at least 52 feet deep to accommodate LNG tanker ships incurring substantial infrastructure costs. Brownsville Port Director, Eduardo Campirano, in December 2016 noted that preliminary estimates for deepening the channel would be in the range of $\$ 250$ million and would take at least three years to complete with the estimate at the time that the dredging of the channel would be completed by 2020 (Chapa December 16, 2020). However, later estimates have come in at $\$ 350$ million, half of which is alleged to be paid by NextDecade 
Corporation pending whether they move forward with making a final investment decision on building the Rio Grande LNG complex in 2021 (Veazey November 20, 2020). Nothing has started as of December 2020 and the channel deepening funding could be in jeopardy if NextDecade Corporation decides not to go forward with the Rio Grande LNG project. The economic and environmental resistance to these corporate initiatives by local communities is laid out in the next section.

\section{Resistance: Save RGV from LNG versus Corporate LNGs}

"When we first learned that big companies wanted to build LNG plans here in Brownsville at the port, May 2014, we could not believe anyone would ever do that. We came to find out that the plans had been in the works for years before, but the public did not know. Now six years later, we have been involved in many campaigns to impede the development of LNG terminals at the Port of Brownsville" - Jim Chapman, President of Friends of the Wildlife Corridor, and leader in Save RGV from LNG. Email sent to author, November 9, 2020 .

"Texas LNG plans to destroy a pre-Columbian archaeological site called Garcia Pasture with the remains of our ancestors and villages. These pristine lands where the Rio Grande $L N G$, Texas $L N G$, and Annova $L N G$ companies plan to bulldoze and spew toxic pollution are sacred to the Carrizo Comecrudo Tribe, and the companies did not consult with us, " said Juan Mancias, Chairman of the Carrizo Comecrudo Tribe of Texas (Wolinsky, July 10, 2019, para. 6).

This section examines narratives of resistance regarding LNG construction projects. Historically, FERC has been overwhelmingly in favor of development projects. From 1987 to 2016 may have approved nearly $100 \%$ of the projects proposed. The notable exception was the Jordan Cove (Oregon) export project in March 2016 (Sickinger 2016, Garrett 2018), where the project was delayed rather than completely stopped. Because of this ambiguity, groups are still working towards delaying if not stopping the project. While FERC approved the project in March 2020 (Danko March 19, 2020), the state of Oregon stepped in to delay if not stop the project (Sickinger February 9, 2021). The Jordan Cove project represents a model of resistance for Laguna Madre communities. In the Laguna Madre region, this resulted in the emergence of Save $R G V$ from $L N G$. The goal, of course, is to limit the impact of federal agencies that rubber stamp fossil fuel projects. 
Grassroots support and community resistance in the Rio Grande Valley have been led by the local chapter of the Sierra Club. The primary tactic used initially was to educate the people in the cities of South Padre Island, Laguna Vista, Port Isabel, Long Island Village, and Laguna Heights concerning the uncertainty, risk, and stigma from LNG refineries in close proximity. For example, the Texas LNG terminal site is less than 2 miles from Port Isabel high school. The groups opposed to the LNG terminals have held meetings to expose the risks for air, water, soil and light pollution from the refineries and pipelines. The risks were communicated by media, and social media campaigns as well. Through these tactics, the leadership of the Sierra Club brought various community groups together under the Save RGV from $L N G$ campaign, which included a blog, Twitter, and Facebook accounts.

The campaign Save RGV from LNG, organized protests on August 11, 2015, at the Port Isabel Convention Center during the FERC LNG scoping meeting. The LNG protestors were not allowed into the scoping meeting. In contrast, Annova LNG, Texas LNG, and Rio Grande LNG were allowed to have "information" tables inside the center. FERC established rules that citizens could come to the meeting and have their testimony taken individually and not collectively. There were 30 comments by 165 citizens in the Laguna Madre area who filed as intervenors in June 2016 both for and against Texas LNG. A partial list in favor included Texas Lt. Governor Dan Patrick, Los Fresnos Area Chamber of Commerce, Brownsville Navigation District, and the South Padre Island Chamber of Commerce. Groups that were against Texas LNG included members of the U.S. National Park Service, Sierra Club, City of South Padre Island, Sea Turtle Inc., Town of Laguna Vista, Vecinos Para El Bienstar de la Communidad Costera, Texas Shrimp Association, Lower Laguna Madre Foundation, Friends of the Wildlife Corridor, and the City of Port Isabel (Chapa June 17, 2016). By August 2016 when Annova LNG, the first of the three LNG terminals, announced their intentions to construct their liquefied natural gas refinery in the Port of Brownsville, hundreds of Laguna Madre citizens and fifteen groups sought an injunction with FERC against the LNG corporations. Chapa (August 18, 2016) listed the groups objecting to Annova LNG:

1. Friends of Laguna Atascosa National Wildlife Refuge

2. Sea Turtle, Incorporated

3. Defenders of Wildlife

4. Lower Laguna Madre Foundation

5. Long Island Village Owners Association 
6. Center for Biological Diversity

7. Sierra Club

8. Vecinos Para el Bienestar de la Comunidad Costera

9. City of South Padre Island

10. City of Port Isabel

11. Shrimp Outlet

12. Burnell Marine \& Supply

13. Shrimp Outlet Farmers Market

14. Texas Shrimp Association

15. Brownsville/ Port Isabel Shrimp Processors Association

Successful outcomes from these acts of resistance to LNG corporations have included stopping tax abatements for Annova LNG and Rio Grande LNG in the Point Isabel Independent School District that serves the lower Laguna Madre region. All three LNGs were asked to leave the area and not locate their terminals in the Port of Brownsville by resolutions passed by the city councils of South Padre Island, Laguna Vista, and Port Isabel. This was due in large part to lobbying efforts and meeting attendance by members of Save RGV from $L N G$ coalition and locally affected small business owners. The LNGs were able to obtain political support from area local chambers of commerce by buying memberships. Additionally, letters of support for the LNGs have come from state representatives, a state senator, a Congressional Representative, and both U.S. Senators from Texas (among others). Despite resistance to the LNGs, the Cameron County Commissioner's Court approved a tax abatement for Rio Grande LNG in October 2017 (Garrett 2018). Two years later, they similarly gave Annova LNG a tax abatement despite opposition from Rebekah Hinojosa, Sierra Club organizer, stating....

By approving this terrible tax break deal, Cameron County commissioners failed their constituents who will bear the costs of Annova LNG's polluting facility...The communities of South Padre Island, Port Isabel, Laguna Vista and Long Island Village have all passed anti-LNG resolutions. Annova LNG would pollute Latinx communities and poses a huge environmental risk to the Rio Grande Valley (Reyna October 1, 2019, para. 13)

The LNGs emphasize narratives of economic development and job creation that appeal to elected officials in one of the poorest regions in Texas and the U.S. with chronically high unemployment (Ura and Wang September 13, 2018). Save RGV from $L N G$ and other local resisters to the LNGs find it challenging to counter economic arguments with politicians in a region that is both chronically poor and susceptible to exploitation by the fossil fuel industries. 
The Carrizo-Comecrudo people additionally contributed to trying to stop funding of LNGs, particularly Rio Grande LNG, by protesting French investment banks such as BNP Paribas and Société Générale and seeking allies such as Friends of the Earth - France, thwarting the corporations obtaining funding (Wolinksy July 10, 2019). The Carrizo-Comecrudo tribe of Texas is not federally recognized by the U.S. government, which makes it difficult to have standing while taking any legal action against the LNGs that are attempting to seize their lands and their associated cultural heritage sites in the lower Rio Grande Valley.

The Save RGV from $L N G$ network has utilized the legal system in federal and state courts to stop LNGs from building their pipelines and refineries. Recent examples of lawsuits suing FERC, other federal departments and agencies, the Port of Brownsville Navigation District, and the Texas Commission on Environmental Quality (TCEQ) are shown in Table 1 (see below).

$<$ Table 1 goes here $>$

As of November 2020, there are eleven lawsuits by various affected groups and communities attempting to stop the LNGs from locating along the Brownsville Shipping channel. The cases are ongoing.

\section{Matches and tinder - immediate risks to the Laguna Madre region: SpaceX, the volatility of LNG and potential terrorism risks on the Mexico-U.S. border}

"They went from proposing a few launches per year of an already field-tested rocket to ongoing experimentation of untested technology without doing the studies that would ensure environmental protection and public safety and without giving the local community a chance to have a say," said Jim Chapman, president of Friends of the Wildlife Corridor (Foust, November 25, 2020, para. 9).

The people who dwell in the communities of South Padre Island, Port Isabel, Laguna Vista, Laguna Heights, Long Island Village could be endangered by LNGs building refineries and beginning their operations. The Annova LNG terminal was scheduled to be built along the Brownsville shipping channel is approximately 5 miles from the SpaceX launch pad in Boca Chica with Rio Grande LNG and Texas LNG also nearby. Sierra Club's Rebekah Hinojosa noted after FERC approved the location of the Annova LNG terminal in March 2017 they would be launching Falcon 9 and the Falcon Heavy SpaceX rockets dangerously close to the Annova LNG terminal, located on the south shore of the Brownsville Ship Channel, sharing State Highway 4 
with the launch site. For environmentalists, Hinojosa said the worst-case scenario is a SpaceX rocket failure causing an explosion at one or all three of the proposed LNG facilities" (Chapa March 23, 2017, para. 18). The Federal Aviation Administration (FAA) was part of the FERC approval process. However, since the approval, SpaceX's Elon Musk decided to launch the much more powerful Starship SN Series and Falcon Super Heavy rockets that are being considered for approval by the FAA at Boca Chica launch site (Arevalo November 23, 2020). The previous FERC/FAA analysis showed some risk due to the proximity of the LNG terminals to the SpaceX launch pad. The potential for risk to the communities remains uncertain while the FAA conducts a thorough analysis.

Liquefied natural gas can be hazardous in large quantities such as when located in LNG terminal storage containers and onboard LNG tanker ships. Garrett (2018, citing MIT Professor James Fay in Hurst February 2008, 3) notes "Once ignited, as is very likely when the spill is initiated by a chemical explosion, the floating LNG pool will burn vigorously [and] Like the attack on the World Trade Center in New York City, there exists no relevant industrial experience with fires of this scale from which to project measures for securing public safety." The Council on Foreign Relations report in 2006 (Kaplan February 27, 2006) and a February 2007 Government Accountability Office report illustrated the potential of a terrorist attack on LNG tankers (Garrett, 2018). Given these risks, LNG tankers must be escorted by the U.S. Coast Guard when they approach populated areas. This raises additional issues for residents in the lower Laguna Madre region near the Port of Brownsville.

\section{Conclusion: The spectacle of global market conditions, collateral damage, and profitability for LNGs - Implications for future research}

The Covid-19 pandemic has been harmful to national economies generally and to fossil fuel industries in particular. Profit margins have suffered since LNGs leased property to build their refineries and deepen the Brownsville shipping channel limiting the corporations' interest in incurring risk from investment. Save RGV from $L N G$ leader, Stefanie Herweck, noted in 2016 prior to the coronavirus outbreak that....

"From every angle, this does not look like a sustainable project," said Stefanie Herweck with Save RGVfrom LNG... [Herweck]said the Texas LNG project and two similar ones also proposed for the Port of Brownsville will pollute, disrupt tourism and pose a public 
safety risk. Herweck [stated]... from an economic standpoint, Texas LNG, Annova LNG and Rio Grande LNG all missed the opportunity to take advantage of higher commodity prices in Asia. "The Brownsville projects are way down the queue in the process. It's hard to see how they will be profitable" (Chapa, April 8, 2016, para. 4-7).

Save RGV from $L N G$ has attempted to redirect narratives against the LNGs and their global corporate support to limit or avoid problems of collateral damage (Bauman 2011). They have had some success so far as exhibited by their actions against FERC and the LNGs. All three LNG projects are well behind schedule yet continue to lease land from the Port of Brownsville as they weigh whether to continue forward with development while facing community resistance. As noted above, Annova LNG has halted the construction of its terminal claiming that a poor natural gas market was the cause. Save RGV from $L N G$ activists have welcomed the cancellation of the project claiming, "Today's victory is the result of six years of tireless efforts of the Rio Grande Valley communities in South Texas who have written comments, attended hearings, protested banks, and more to protect their health, their precious coastline, and the climate from Annova LNG's proposed fracked gas project" (Wilkins March 23, 2021, para. 3). Regardless of context, the threats of risk, uncertainty, and stigma loom large. People in general and property owners in particular historically balk at controversial projects. Combining these longstanding fear narratives with analysis we discover pathways for a critically informed postmodern approach (Garrett 2018) to grassroots resistance by combining the work of Debord and Bauman. As such, the lower Rio Grande Valley case study illustrates how community resistance to the opportunistic hegemony of globalization efforts may counter the more hazardous aspects of neoliberal capitalism. Whether the two remaining LNGs locate to the Port of Brownsville and begin operations remains to be seen as the capabilities of Save RGV from $L N G$ have been demonstrably successful in terms of delaying the development thus far and, perhaps, stopping the Annova LNG project. Additionally, Texas LNG and Rio Grande LNG lost legal arguments brought about by a Federal Court of Appeals lawsuit of the Save RGV from LNG coalition that resulted in the LLCs having to provide a social justice rationale - taking into full account the adverse impact on economically depressed minority communities - for their climate analyses that were missing from their original FERC approved invitation to proceed with building their respective LNG terminals (Malo, August 3, 2021). The local resistance continues. However, the court upheld the authorizations for the continuance of the pipelines and terminals if they comply with the court ordered recommendations. As it stands, neo-liberal capitalism remains a powerful political and 
economic force yet to be fully reckoned with in the lower Rio Grande Valley's Laguna Madre region. Profits and exploitation of economically poor regions continue at the expense of communities and the environment.

Neoliberal globalization continues. The research presented here using concepts of Debord's (2006/1967) spectacle and Bauman's collateral damage are useful for framing the social construction that underlies the hegemonic power of global corporations and their government allies against local communities, particularly in economically depressed regions like Laguna Madre. The theoretical framework developed in this article has implications for future investigations into the how communities may resist the onset of unwanted corporations interested in exploiting and extracting resources, leaving locals with the consequences of increased environmental pollution, displaced local economies, and other potential threats. The authors invite other scholars to pursue these areas of inquiry to understand the implications of both corporate expansion and global responsibility.

\section{References:}

Agamben, G. (1993). The coming community. Minneapolis, MN: University of Minnesota Press. Annova LNG. (n.d.) Our facility. https://annovalng.com/ (accessed 11/17/20).

Ardalan, K. (2016) Paradigms in Political Economy. London: Routledge.

Arevalo, E. (November 23, 2020). FAA is evaluating SpaceX's plan to launch starship \& super heavy rocket in South Texas. Tesmanian. https:/www.tesmanian.com/blogs/tesmanianblog/starship-faa (accessed 11/25/20).

Bauman, Z. (2011). Collateral damage: Social inequalities in a global age. Cambridge, MA: Polity Press.

Best, S. \& D. Kellner. (2001). The postmodern adventure: Science, technology, and cultural studies in the third millennium. Guilford Press, New York, NY.

Boje, D.M. (1995). Stories of the storytelling organization: A postmodern analysis of Disney as “Tamara-Land." Academy of Management Journal, 39/4: 997-1035.

Boje, D.M. (2001). Narrative Methods for Organizational \& Communication Research. Thousand Oaks, CA Sage Publications.

Boje, D.M. (2008). Story ethics. In Critical theory ethics for business and public administration. D.M. Boje, editor, pp. 97-117. Charlotte, NC: Information Age Publishing. 
Center for Liquefied Natural Gas. (n.d.) $L N G$ and the environment. https://www.lngfacts.org/lngand-the-environment/ (accessed 11/17/20).

Chapa, S. (April 24, 2015). LNG exports change the game for two South Texas ports. San Antonio Business Journal. https://www.bizjournals.com/sanantonio/print-edition/2015/04/24/lngexports-change-the-game-fortwo-south-texas.html (accessed 8/29/20).

Chapa, S. (April 8, 2016). Environmentalists: Saturated markets can't sustain more LNG export terminals. San Antonio Business Journal.

https://www.bizjournals.com/sanantonio/news/2016/04/08/markets-cant-sustain-new-lngexportterminals.html (accessed 8/29/20).

Chapa, S. (June 17, 2016). Texas LNG supporters \& opponents. San Antonio Business Journal. https://www.bizjournals.com/sanantonio/print-edition/2016/06/17/texas-lngsupportersopponents.html (accessed 8/29/20).

Chapa, S. (August 18, 2016). Environmentalists bombard Annova LNG application with motions to intervene. San Antonio Business Journal. https:/www.bizjournals.com/sanantonio/blog/eagleford-shale-insight/2016/08/enivronmentalistsbombard-annova-lng-application.html (accessed $8 / 29 / 20)$.

Chapa, S. (December 20, 2016). Port of Brownsville gets permission to deepen its channel, buthow to pay for it? San Antonio Business Journal. https:/www.bizjournals.com/sanantonio/news/2016/12/20/port-of-brownsville-can-deepenitschannel.html (accessed 8/29/20).

Chapa, S. (March 23, 2017). Report: SpaceX and proposed LNG plant can safely be neighbors. San Antonio Business Journal. https:/www.bizjournals.com/sanantonio/news/2017/03/23/spacex-and-proposed-lng-plant-canbeneighbors.html (accessed 8/29/20).

Clark, S. (April 25, 2012). Cargo up 16 percent over 2010 at Port of Brownsville. Brownsville Herald. https://www.brownsvilleherald.com/news/article_e91a55cd-bc63-5c26-8c7db2585656ac82.htm (accessed 3/28/16).

Closser, B. M. (2001). Fuel-oil contamination of a residence: A case study in stigma. The Appraisal Journal, 69(3), 307-311.

Corso, J. (August 8, 2019). Brownsville: The next LNG capital? San Antonio Business Journal. https:/www.bizjournals.com/sanantonio/news/2019/08/08/brownsville-the-next-lng-capital.html (accessed 8/29/20).

Danko, P. (March 19, 2020). Feds approve Oregon's controversial Jordan Cove project. Portland Business Journal. https://www.bizjournals.com/portland/news/2020/03/19/feds-approveoregonscontroversial-jordan-cove.html (accessed 11/23/20).

Dear, M. (1992). Understanding and overcoming the NIMBY syndrome. Journal of the American planning association, 58(3), 288-300. 
Debord, G. Society of the spectacle (2006/1967).

https://www.marxists.org/reference/archive/debord/society.htm (accessed 9/12/20).

Devine-Wright, P. (Ed.). (2014). Renewable energy and the public: from NIMBY to participation. New York, Routledge.

Foust, J. (November 25, 2020). SpaceX ready for Starship suborbital flight as FAA begins new environmental study." Space News. https://spacenews.com/spacex-ready-for-starship-suborbitalflight-as-faa-begins-new-environmental-study/ (accessed 11/26/20).

Garrett, T.M. (2018). Proposed liquefied natural gas (LNG) terminals in the Rio Grande valley of Texas - citizen group participation versus natural gas corporations. Journal of Global Responsibility, 9/1: 58-72.

Gibson, T. A. (2005). NIMBY and the civic good. City \& community, 4(4), 381-401.

Government Accountability Office (GAO). (February 2007). Maritime security: public safety consequences of a terrorist attack on a tanker carrying liquefied natural gas need clarification, GAO-07-316. www.gao.gov/assets/260/256821.pdf (accessed 11/25/20).

Heilman, J., \& Sementelli, A. (2020). Rethinking Habermas, from the ideal to the individual: a practical application of critical management theory. Administrative Theory \& Praxis, 1-13.

Hopper, L. (March 12, 2021) Health risk? More than 500,000 Americans live within 3 miles of natural gas flares. Phys.org. https://phys.org/news/2021-03-health-americans-miles-naturalgas.html (accessed 3/16/21).

Hurst, C. (February 2008). The terrorist threat to liquefied natural gas: Fact or fiction? Institute for the Analysis of Global Security. www.iags.org/hurstlng0208.pdf (accessed 11/25/20).

Hydrocarbons-Technology.com (March 23, 2021) Annova LNG aborts development of \$3bn LNG export project in US. https://www.hydrocarbons-technology.com/news/annova-lng-abortsexport-project/ (accessed 5/16/21).

Ives, P. (2004). Language and hegemony in Gramsci. London: Pluto Press.

Kaplan, E. (February 27, 2006) Liquefied natural gas: A potential terrorist target? Council on Foreign Relations. https://www.cfr.org/backgrounder/liquefied-natural-gas-potential-terroristtarget (accessed 11/25/20).

Malo, S. (August 3, 2021) FERC must redo climate analysis for Texas LNG projects - D.C. Circuit. Reuters. https://www.reuters.com/legal/litigation/ferc-must-redo-climate-analysis-texaslng-projects-dc-circuit-2021-08-04/ (accessed 8/4/21).

Milward, H. B., \& Provan, K. G. (2000). Governing the hollow state. Journal of public administration research and theory, 10(2), 359-380.

Moura, D. P., \& Miller, H. T. (2019). On Legitimacy: Is Public Administration Stigmatized? Administration \& Society, 51(5) 770-794. 
Mundy, B. (1992). Stigma and value. The Appraisal Journal, 60(1) 7-13.

NextDecade Corporation. (n.d.) Rio Grande LNG: Project facts. https://www.nextdecade.com/rio-grande-lng/ (accessed 11/17/20).

Ogbor, J. O. (2001). Critical theory and the hegemony of corporate culture. Journal of Organizational Change Management.14(6), 590-608.

Reyna, N. (October 1, 2019). Done Deal: County commissioners approve tax abatement for Annova LNG. Valley Morning Star. https://www.valleymorningstar.com/2019/10/01/done-dealcounty-commissioners-approve-tax-abatement-annova-lng/ (accessed 11/23/20).

Rubinstein Reiss, D. (2012). The benefits of capture. Wake Forest L. Rev., 47, 569-610.

Schlosberg, D. (2009). Defining environmental justice: Theories, movements, and nature. Oxford University Press.

Simons, R. A., \& Sementelli, A. (1997). Liquidity loss and delayed transactions with leaking underground storage tanks. Appraisal Journal, 65, 255-260.

Sementelli, A., \& Simons, R. A. (1997). Regulation of leaking underground storage tanks: policy enforcement and unintended consequences. Economic Development Quarterly, 11(3), 236-248.

Sickinger, T. (March 28, 2016). Feds reject Jordan Cove LNG terminal. The Oregonian. www.oregonlive.com/environment/index.ssf/2016/03/feds_deny_jordan_cove_lng_term.html\#co mments (accessed 3/28/16).

Sickinger, T. (February 9, 2021). Feds uphold state denial on Jordan Cove LNG's coastal zone permit, another roadblock for the controversial project. The Oregonian.

https://www.oregonlive.com/environment/2021/02/feds-uphold-state-denial-on-jordan-covelngs-coastal-zone-permit-another-roadblock-for-the-controversial-project.html (accessed 2/21/21).

Texas LNG. (n.d.) Texas LNG summary. https://txlng.com/about/texas-lng-summary.html (accessed 11/17/20).

Union of Concerned Scientists. (February 3, 2014). Infographic: the climate risks of natural gas. www.ucsusa.org/clean_energy/our-energy-choices/coal-and-other-fossil-

fuels/infographicclimate-change-risks-natural-gas.html\#.Vvbyr-IrIqM (accessed 11/17/20).

United States Geological Survey. (n.d.) Overview. https://www.usgs.gov/mission-areas/waterresources/science/hydraulic-fracturing?qt-science_center_objects $=0 \# q t$-science_center_objects (accessed 11/17/20).

Ura, A. \& E. Wang. (September 13, 2018). Poverty in Texas drops to lowest levels in more than a decade. Texas Tribune. https://www.texastribune.org/2018/09/13/texas-poverty-census-2017lowest-levels-decade/ (accessed 11/23/20).

Van de Graaf, T., \& B.K. Sovacool (2020) Global Energy Politics, Cambridge, UK: Polity Press. 
Veazey, M.V. (November 20, 2020). Texas LNG developer selects channel dredging specialist. Rigzone.

https://www.rigzone.com/news/texas_lng_developer_selects_channel_dredging_specialist-20nov-2020-163903-article/ (accessed 11/25/20).

Wilkins, B. (March 23, 2021). Activists welcome cancellation of Texas LNG terminal. EcoWatch. https:/www.ecowatch.com/lng-terminal-texas-cancelled-2651180486.html (accessed $6 / 16 / 21)$.

Wolinksy, J. (July 10, 2019). Environmentalists warn banks on Rio Grande LNG projects. Value Walk. https:/www.valuewalk.com/2019/07/rio-grande-valley/ (accessed 11/26/20).

Yarbrough, B. V., \& Yarbrough, R. M. (1987). Cooperation in the liberalization of international trade: after hegemony, what? International Organization, 41(1) 1-26.

Yarbrough, B. V., \& Yarbrough, R. M. (1987b). Institutions for the governance of opportunism in international trade. Journal of Law, Economics, and Organization, 3(1), 129-139.

\section{Endnote}

[1] The theoretical concept "postmodernism" used in this manuscript follows the work of Best \& Kellner (2001). Postmodern theoretical approaches often critique and challenge structural functional approaches to science, technology, and culture. Our application reflects elements of critical postmodernity given that we expose the exploitation of LNGs through the use of hegemonic action on Laguna Madre communities since they are less powerful politically and economically for resource extraction. This case study bridges critical theory and postmodernism while underscoring the contributions of narrative analysis (Boje, 2001). 
Table 1: Save RGV from $L N G$ Court Litigation "LNG Lawsuit" Tracker

\begin{tabular}{|c|c|c|c|c|c|c|}
\hline $\begin{array}{l}\text { Plaintiffs and } \\
\text { Defendants }\end{array}$ & $\begin{array}{l}\text { LNG } \\
\text { Company }\end{array}$ & $\begin{array}{l}\text { Date } \\
\text { Filed }\end{array}$ & $\begin{array}{l}\text { Plaintiff } \\
\text { Attorneys }\end{array}$ & $\begin{array}{l}\text { Reason for } \\
\text { Lawsuit }\end{array}$ & Status & $\begin{array}{l}\text { Current } \\
\text { Court }\end{array}$ \\
\hline $\begin{array}{l}\text { Vecinos, }{ }^{*} \text { Sierra Club, } \\
\text { Port Isabel, } \\
\text { SaveRGVfromLNG v. } \\
\text { FERC }\end{array}$ & $\begin{array}{l}\text { Rio Grande } \\
\text { LNG/Rio Bravo } \\
\text { Pipeline }\end{array}$ & $2 / 20 / 2020$ & $\begin{array}{l}\text { Nathan Matthews, } \\
\text { Erin Gaines, Gilberto } \\
\text { Hinojosa }\end{array}$ & $\begin{array}{l}\text { FERC violated } \\
\text { NEPA*** \& } \\
\text { Natural Gas Act } \\
\text { in their decision } \\
\text { to grant permit }\end{array}$ & $\begin{array}{l}\text { Oral Arguments } \\
\text { Pending }\end{array}$ & $\begin{array}{l}\text { D.C. Court of } \\
\text { Appeals }\end{array}$ \\
\hline $\begin{array}{l}\text { Vecinos,* Sierra Club, } \\
\text { Port Isabel, } \\
\text { SaveRGVfromLNG v. } \\
\text { FERC }\end{array}$ & Annova LNG & $3 / 27 / 2020$ & $\begin{array}{l}\text { Nathan Matthews, } \\
\text { Erin Gaines, Gilberto } \\
\text { Hinojosa }\end{array}$ & $\begin{array}{l}\text { FERC violated } \\
\text { NEPA*** \& } \\
\text { Natural Gas Act } \\
\text { in their decision } \\
\text { to grant permit }\end{array}$ & $\begin{array}{l}\text { Oral Arguments } \\
\text { Pending } \\
\text { Combined with } \\
\text { Texas LNG }\end{array}$ & $\begin{array}{l}\text { D.C. Court of } \\
\text { Appeals }\end{array}$ \\
\hline $\begin{array}{l}\text { Vecinos,* Sierra Club, } \\
\text { Port Isabel, } \\
\text { SaveRGVfromLNG v. } \\
\text { FERC }\end{array}$ & Texas LNG & $3 / 27 / 2020$ & $\begin{array}{l}\text { Nathan Matthews, } \\
\text { Erin Gaines, Gilberto } \\
\text { Hinojosa }\end{array}$ & $\begin{array}{l}\text { FERC violated } \\
\text { NEPA*** \& } \\
\text { Natural Gas Act } \\
\text { in their decision } \\
\text { to grant permit }\end{array}$ & $\begin{array}{l}\text { Oral Arguments } \\
\text { Pending } \\
\text { Combined with } \\
\text { Annova LNG }\end{array}$ & $\begin{array}{l}\text { D.C. Court of } \\
\text { Appeals }\end{array}$ \\
\hline $\begin{array}{l}\text { Sierra Club, Defenders } \\
\text { of Wildlife v. U.S. Dept. } \\
\text { of Interior }\end{array}$ & $\begin{array}{l}\text { Rio Grande } \\
\text { LNG/Rio Bravo } \\
\text { Pipeline }\end{array}$ & $4 / 14 / 2020$ & $\begin{array}{l}\text { Devora Ancel, Eric } \\
\text { Huber, Reba } \\
\text { McCreary }\end{array}$ & $\begin{array}{l}\text { Endangered } \\
\text { Species } \\
\text { Violations } \\
\text { regarding } \\
\text { Ocelot survival } \\
\end{array}$ & $\begin{array}{l}\text { Oral Arguments } \\
\text { Pending }\end{array}$ & $\begin{array}{l}\text { U.S. Fifth } \\
\text { Circuit Court } \\
\text { of Appeals }\end{array}$ \\
\hline $\begin{array}{l}\text { Sierra Club, Defenders } \\
\text { of Wildlife v. U.S. Dept. } \\
\text { of Interior }\end{array}$ & Annova LNG & $4 / 20 / 2020$ & $\begin{array}{l}\text { Devora Ancel, Eric } \\
\text { Huber, Reba } \\
\text { McCreary }\end{array}$ & $\begin{array}{l}\text { Endangered } \\
\text { Species } \\
\text { Violations } \\
\text { regarding } \\
\text { Ocelot survival } \\
\end{array}$ & $\begin{array}{l}\text { Oral Arguments } \\
\text { Pending }\end{array}$ & $\begin{array}{l}\text { U.S. Fifth } \\
\text { Circuit Court } \\
\text { of Appeals }\end{array}$ \\
\hline $\begin{array}{l}\text { Fishermen \& Shrimpers } \\
\text { of the RGV, Sierra Club, } \\
\text { SaveRGVfromLNG v. } \\
\text { U.S. Army Corps of } \\
\text { Engineers }\end{array}$ & $\begin{array}{l}\text { Rio Grande } \\
\text { LNG/Rio Bravo } \\
\text { Pipeline }\end{array}$ & $7 / 23 / 2020$ & $\begin{array}{l}\text { Erin Gaines, Nathan } \\
\text { Matthews }\end{array}$ & $\begin{array}{l}\text { Clean Water } \\
\text { Act violations, } \\
\text { wetland } \\
\text { destruction }\end{array}$ & $\begin{array}{l}\text { Oral Arguments } \\
\text { Pending; } \\
\text { USACE has } \\
\text { suspended } \\
\text { permit }\end{array}$ & $\begin{array}{l}\text { U.S. Fifth } \\
\text { Circuit Court } \\
\text { of Appeals }\end{array}$ \\
\hline $\begin{array}{l}\text { Port Isabel, JJ Zamora, } \\
\text { Martin Cantu v. } \\
\text { Brownsville Navigation } \\
\text { District }\end{array}$ & $\begin{array}{l}\text { Rio Grande } \\
\text { LNG, Annova } \\
\text { LNG, Texas } \\
\text { LNG }\end{array}$ & $1 / 27 / 20$ & Gilbert Hinojosa & $\begin{array}{l}\text { All three LNG } \\
\text { leases are } \\
\text { obstructions of } \\
\text { public rights } \\
\end{array}$ & $\begin{array}{l}\text { Dismissed// } \\
\text { Appealed }\end{array}$ & $\begin{array}{l}13^{\text {th }} \text { U.S. Court } \\
\text { of Appeals }\end{array}$ \\
\hline $\begin{array}{l}\text { Port Isabel, Fishermen \& } \\
\text { Shrimpers of RGV, } \\
\text { Vecinos,* v. Texas } \\
\text { Commission on } \\
\text { Environmental Quality } \\
\text { (TCEQ) }\end{array}$ & $\begin{array}{l}\text { Rio Grande } \\
\text { LNG/Rio Bravo } \\
\text { Pipeline }\end{array}$ & $2 / 20 / 2020$ & $\begin{array}{l}\text { Erin Gaines, Gilbert } \\
\text { Hinojosa }\end{array}$ & $\begin{array}{l}\text { Challenging } \\
\text { TCEQ air } \\
\text { permit }\end{array}$ & $\begin{array}{l}\text { Lost on } \\
\text { standing }\end{array}$ & $\begin{array}{l}\text { U.S. Fifth } \\
\text { Circuit Court } \\
\text { of Appeals }\end{array}$ \\
\hline $\begin{array}{l}\text { Sierra Club, Vecinos, * } \\
\text { Shrimpers \& Fishermen } \\
\text { of the RGV, Carrizo } \\
\text { Comecrudo Tribe, } \\
\text { SaveRGVfromLNG v. } \\
\text { FERC }\end{array}$ & $\begin{array}{l}\text { Rio Grande } \\
\text { LNG/Rio Bravo } \\
\text { Pipeline }\end{array}$ & $7 / 16 / 2020$ & $\begin{array}{l}\text { Nathan Matthews, } \\
\text { Erin Gaines }\end{array}$ & $\begin{array}{l}\text { Larger pipeline } \\
\text { / other changes } \\
\text { are contrary to } \\
\text { the public } \\
\text { convenience, } \\
\text { should not have } \\
\text { been approved }\end{array}$ & $\begin{array}{l}\text { FERC } \\
\text { Environmental } \\
\text { Assessment } \\
\text { pending } \\
\text { (originally due } \\
11 / 16 / 2020 \text { ) }\end{array}$ & $\begin{array}{l}\text { D.C. Court of } \\
\text { Appeals }\end{array}$ \\
\hline Vecinos, *v. TCEQ & Texas LNG & $8 / 5 / 2020$ & Erin Gaines & $\begin{array}{l}\text { Challenging } \\
\text { TCEQ air } \\
\text { permit }\end{array}$ & $\begin{array}{l}\text { Oral Arguments } \\
\text { pending }\end{array}$ & $\begin{array}{l}\text { Travis County } \\
\text { District Court }\end{array}$ \\
\hline $\begin{array}{l}\text { City of Port Isabel v. } \\
\text { TCEQ }\end{array}$ & Texas LNG & Unknown & Gilbert Hinojosa & $\begin{array}{l}\text { Challenging } \\
\text { TCEQ air } \\
\text { permit }\end{array}$ & $\begin{array}{l}\text { Oral Arguments } \\
\text { pending }\end{array}$ & $\begin{array}{l}\text { Travis County } \\
\text { District Court }\end{array}$ \\
\hline
\end{tabular}

Source: Based on Jim Chapman, Save RGV newsletter November 9, 2020 titled "What are we doing now..."

SaveRGVfromLNG, saveRGVfromLNG@gmail.com. Sent to the author on Monday, November 9, 2020 at 8:13 PM (Central Time).

*Vecinos para el Bienstar de la Comunidad Costera

** Since this filing, a motion to FERC to intervene and protest has been filed $7 / 16 / 2020$ by Vecinos, ${ }^{*}$ Shrimpers \& Fishermen of the RGV, Carrizo Comecrudo Tribe, Save RGV from LNG, to intervene and protest Enbridge's amendment for changes to the pipeline and other changes that are contrary to the public convenience and necessity. ***National Environmental Policy Act of 1969. 